\title{
POTENTIAL ROLES OF BIOTIC FACTORS IN REGULATING ZOOPLANKTON COMMUNITY DYNAMICS IN JAKARTA BAY SHALLOW WATER COASTAL ECOSYSTEM
}

\author{
Arief Rachman $^{1}$ and Nurul Fitriya ${ }^{1}$ \\ ${ }^{1}$ Research Center for Oceanography \\ Indonesian Institute of Sciences \\ Jl. Pasir Putih I, Ancol Timur, Jakarta Utara 14430 \\ red_rackham_dead@yahoo.com
}

\begin{abstract}
The dynamics in zooplankton abundance were regulated by changes in water physical-chemical parameters and interaction with biotic factors. In this research we examined the relationship between zooplankton community dynamic and important biotic factors, such as predation and food availability, in Jakarta bay. Plankton samplings were done in 10 sampling stations in Jakarta bay, from July to November 2009. Zooplankton samples were collected using horizontal towing method with NORPAC plankton net (mesh size $300 \mu \mathrm{m}$ ). Salinity, water depth, water temperature, and water transparency were measured. Phytoplankton samples were also collected with the same method as zooplankton, using Kitahara plankton net (mesh size $80 \mu \mathrm{m}$ ). Zooplankton taxas were grouped into two groups, the prey and predatory zooplankton. The results showed that there were two different patterns in zooplankton groups dynamic i.e., the single and double peak. The abundance peak in most zooplankton groups, such as copepods, cirripeds, luciferids, and tunicates, were induced by the high food availability during the phytoplankton bloom in August. The high abundance of prey zooplankton groups in August was responded by the predatory zooplankton groups, resulting in high abundance of predatory zooplankton in adjacent month. The high abundance of ctenophores and chordates (fish larvae) were suggested as the main factor for the low abundance of other zooplankton in September. Physical and chemical factors were not the regulating factors due to the stability of those factors during this research period. Thus we concluded that food availability and predator-prey interaction were the main factors which regulate zooplankton community dynamics in Jakarta bay.
\end{abstract}

Keywords: predator-prey interaction, zooplankton, abundance peak, food availability, phytoplankton bloom

\section{INTRODUCTION}

In marine ecosystem, zooplankton plays an important role as a link in marine food web, connecting the energy transfer between primary producer and higher trophic level organisms, such as shrimps and fishes. Thus any change in zooplankton community could affect the community of the primary producer and higher trophic level organism (Horne and Goldman, 1994; Nybakken and Bertness, 2005; Marques et al., 2008; Hsiao et al., 2011). Zooplankton could also be used as bioindicator for environmental changes and pollution, due to the high sensitivity of some species to any changes in water quality. Variation or fluctuation in water quality might induce seasonal succession and fluctuation in the abundance and distribution of zooplankton in marine ecosystem (Woodmanse, 1958; Hsiao et al., 2011). The physical and chemical parameters that usually limiting the zooplankton abundance and distribution are dissolved oxygen, turbidity, temperature, current, salinity and $\mathrm{pH}$. Food availability, competition, predation 
and disease were other factors which might also limiting the abundance and distribution of zooplankton in marine ecosystems (Horne and Goldman, 1994; Nybakken and Bertness, 2005; Escribano et al., 2007; Hsiao et al., 2011)

Research on zooplankton community dynamics revealed that bottom-up control by phytoplankton was an important factor that determines the abundance and distribution of zooplankton in marine ecosystem. Thus zooplankton maxima were usually occurred right after the occurrence of phytoplankton maxima. Predation by zooplanktivorous fish and carnivorous zooplankton, such as ctenophores and chaetognaths, also capable on limiting the zooplankton abundance and distribution in marine ecosystem (Horne and Goldman, 1994; Uye et al., 2000; Escribano et al., 2007; Reaugh et al., 2007; Sullivan et al., 2007). Predation was known as one of the major ecological forces that regulating the abundance, biomass and composition of the prey organisms in coastal ecosystem. Predator might also act as top-down control to regulate the dynamics of other zooplankton groups, thus might inducing the trophic cascade phenomena to happen in the ecosystem (Pace et al., 1998; Vadeboncoeur et al., 2005; Rilov, 2009).

Biotic factors plays great role when there were no apparent fluctuation on water physical and chemical parameters during seasonal change. In contrast with temperate marine ecosystem, tropical marine shallow water ecosystem has no extreme changes in both water temperature and salinity all over the year. Waves and currents were also played a great role in creating well-mixed or homogenous water columns, thus preventing strong thermocline to form in the shallow water tropical ecosystem. At the same time, land run-off and river outflow carried huge amount of nutrients which enriched the ecosystem, creating a relatively eutrophic condition during all seasons, especially during rainy season. This condition should creating a relatively stable pattern, with low fluctuation, in both phytoplankton and zooplankton abundance in shallow water tropical coastal ecosystem (Wickstead, 1976; Raymont, 1983; Nybakken and Bertness, 2005).

Jakarta bay locates in the north of jakarta and it is a shallow coastal waters.. There are 13 big and small rivers flows to the Jakarta Bay which makes river outflow plays a great role in transporting huge amount of sediments, nutrients and pollutants to its ecosystem. A number of investigations have been done in the Jakarta Bay and shows a decline in plankton diversity but harmful algal blooming was occured more often due to low water quality (Hadikusumah, 2008; Muchtar, 2008; Sidabutar, 2008).

Although research on zooplankton community in Jakarta bay has been done several times, little or no specific attention was given to the interaction between zooplankton community dynamic to some important biological factors, such as predation and food availability. Thus in this research, we examined the relationship between the changes in zooplankton abundance to predation and food availability in Jakarta bay shallow water coastal ecosystem.

\section{METHODS}

The research was conducted in Jakarta bay (Figure 1) which was a shallow marine tropical waters, located in the north of Jakarta, the capital city of Indonesia. The width of Jakarta bay is 22 miles, with maximum depth is $\pm 30 \mathrm{~m}$. There are 13 rivers flows to Jakarta bay. Those rivers are river of Citarum, Bekasi, Marunda, Angke, Ciliwung, Cengkareng, Kamal, Ancol, Karang, Cakung, lencong, Sunter, Pesanggrahan, and Grogol. 
Samples were taken five times at 10 stations around Pluit, Bidadari Island, Sunda Kelapa, Tanjung Priok, and Muara Gembong from July to November 2009.

Zooplankton were taken with NORPAC plankton net (mesh $300 \mu \mathrm{m}$ ) by horizontal towing method at $1 \mathrm{~m}$ depth. The net were towed at 2 knot boat speed in 5 minutes. Samples were preserved in 250 cc plastic bottle and fixated with $4 \%$ borax-neutraled formaldehyde. Salinity, water depth, water transparency, and water temperature were measured in each sampling station. Water depth and transparency were measured with secchi disc, while salinity and water temperature were measured with SCT. Phytoplankton samples were taken with Kitahara plankton net (mesh $80 \mu \mathrm{m}$ ), using the exactly the same method as zooplankton sampling.

Both zooplankton and phytoplankton were identified and counted in Plankton and Primary Productivity Laboratory, Research Center for Oceanography, Indonesian Institute of Sciences. Zooplankton identification and enumeration were done using fraction sub-sampling, taken with $2.5 \mathrm{ml}$ sample pipette, placed in Bogorov disc and observed with LEICA MZ-6 stereo microscope. Phytoplankton were also counted using fraction sub-sampling with $1 \mathrm{ml}$ stample pipette, placed in Sedgewick Rafter Counting Cell (SRCC) and observed with Nikon Diaphot inverted microscope. Phytoplankton cells were not identified.

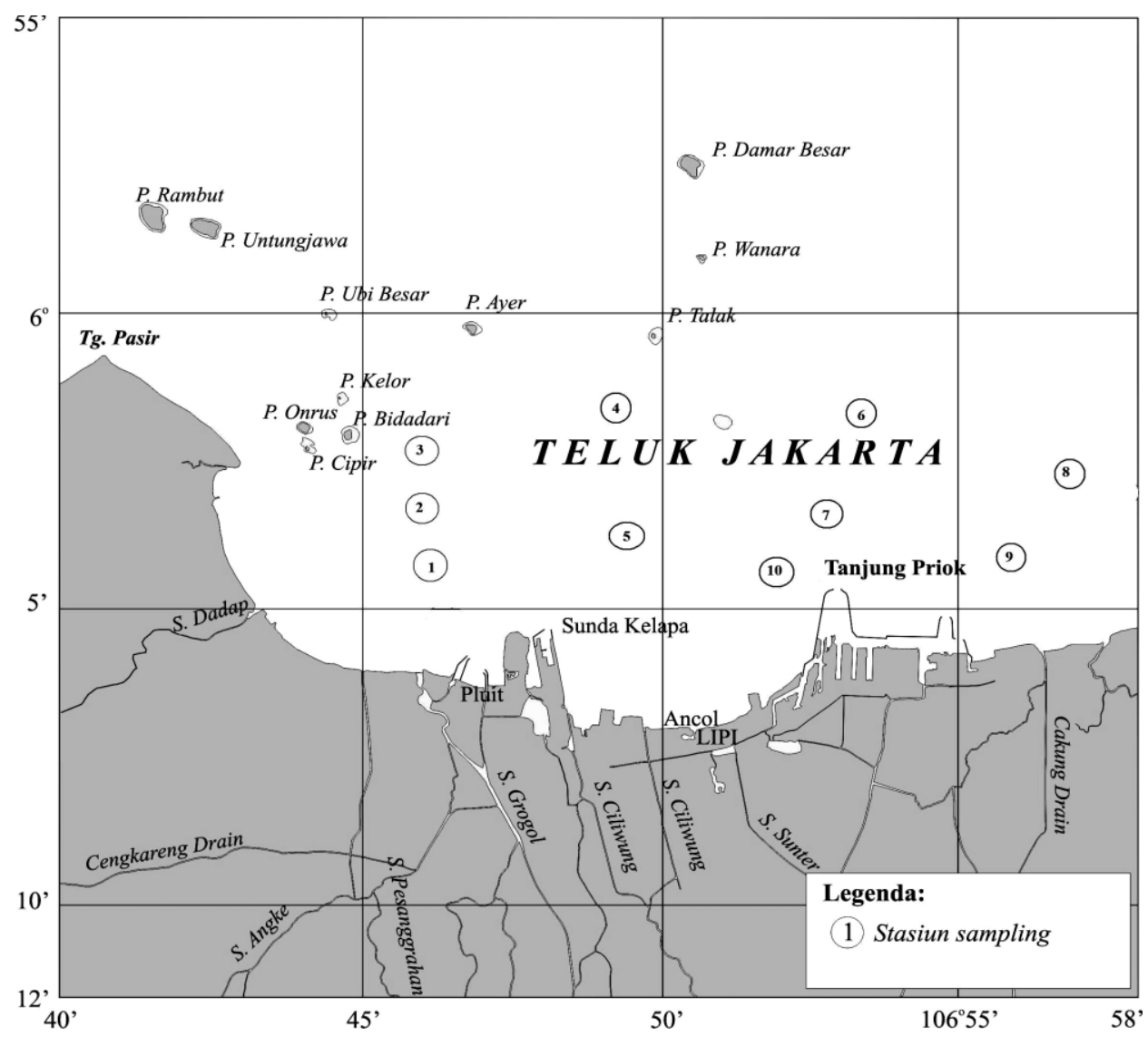

Figure 1. Sampling stations in Jakarta bay during research in July to November 2009.

The stations were located around Pluit, Bidadari Island, Sunda Kelapa, Tanjung Priok, and Muara Gembong. 
Zooplankton was identified and grouped into 15 functional groups, then further grouped into 2 major groups based on its trophic level, which are predator and prey. The predatory group consist of Cnidaria, Ctenophora, Chaetognatha, Polychaeta, and Chordata (fish larvae), while prey group consist of Copepoda, Cladocera, Luciferidae, Mysidae, Malacostraca, Ostracoda, Cirrpedia, Echinodermata, Mollusca, Bryozoa, and Tunicata. Zooplankton identification and grouping was done using reference on plankton taxonomy and ecology (Davis, 1955; Newell and Newell, 1963; Wickstead, 1965; Yamaji, 1966; Raymont, 1983; Lenz, 2000; Nontji, 2008).

The data were analyzed with Pearson cross-correlation method (Bakus 2007), using Biodiversity Pro free ecological statistic software (McAleece et al., 1997). To quantitatively measure the strength of top-down or bottom-up control in the ecosystem, data analysis using Trophic Control Index (Vadeboncoeur et al., 2005).

\section{RESULT AND DISCUSSION}

\subsection{Results}

\subsubsection{General Pattern of Predator and Prey Zooplankton Group Abundance in Jakarta Bay}

From this research it was found that the general pattern of predator and prey zooplankton group abundance were similar (Figure 2). Both groups reached its highest abundance, or peak, in August. After the first peak, the zooplankton abundance was declined in September, before increasing in October and might be regarded as the second peak, although it was not as high as the first peak (Figure $2)$. Although in general the predator and prey zooplankton groups have similar pattern (Figure 2), all taxa in both groups have its own pattern, which sometimes very different from the others (Figure 5 and 6).

Different patterns were occurred when the absolute abundance data was converted into relative abundance. The double peak pattern was still observed in predatory zooplankton group, but the pattern of prey zooplankton was changed into single peak pattern (Figure 3). The predatory zooplankton still has first peak in August and the second peak in October, with a decline in September (Figure 3).

Meanwhile the prey zooplanktons only have one peak and it occurred in September (Figure 3). The pattern of prey zooplankton relative abundance was different from its absolute abundance pattern (Figure 2). It was interesting to note that even when the abundance of prey zooplankton was declined in September, it occupied more proportion in the zooplankton community during adjacent month.

\subsubsection{The Dynamics of Zooplankton Absolute Abundance in Jakarta Bay}

Copepods, cladocerans, cirripeds, luciferids and tunicates were dominant groups in Jakarta bay from July to November 2009 (Figure 4 and 5).. The results also revealed two general patterns on the dynamic of zooplankton abundance, which were (1) single peak, or single maxima; and (2) double peak, or double maxima. Those peaks occurred in both prey and predator zooplankton, although variation on the peak time were observed in some groups (Figure 4). 


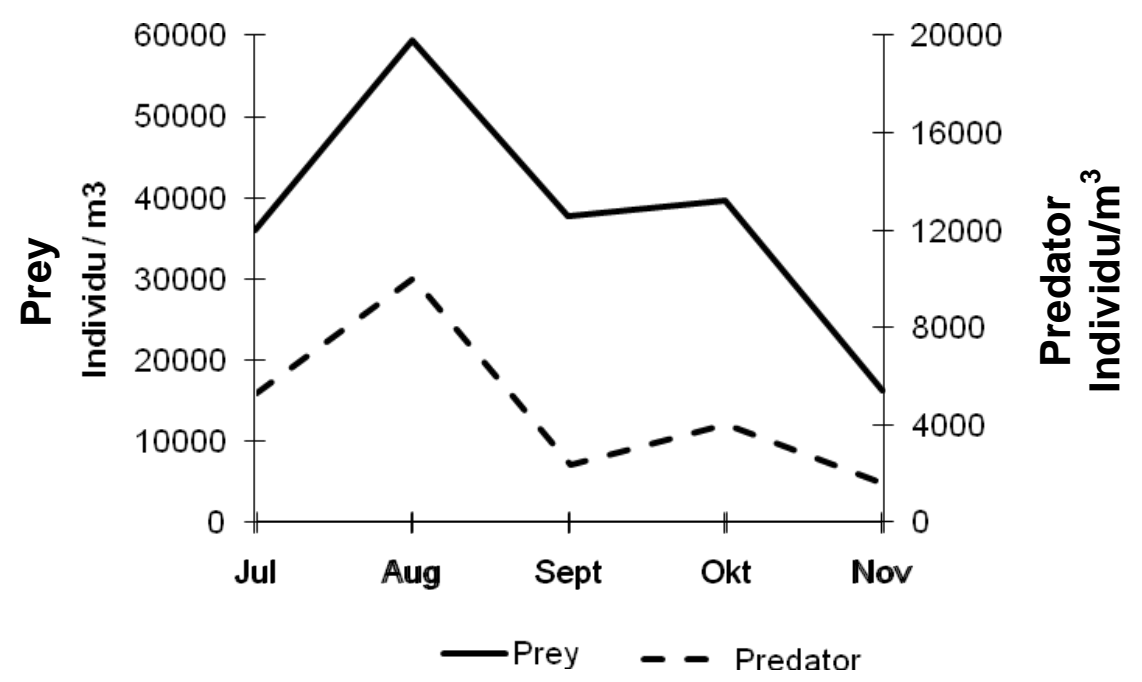

Figure 2. The absolute abundance of prey and predator zooplankton group in Jakarta bay in July to November 2009.

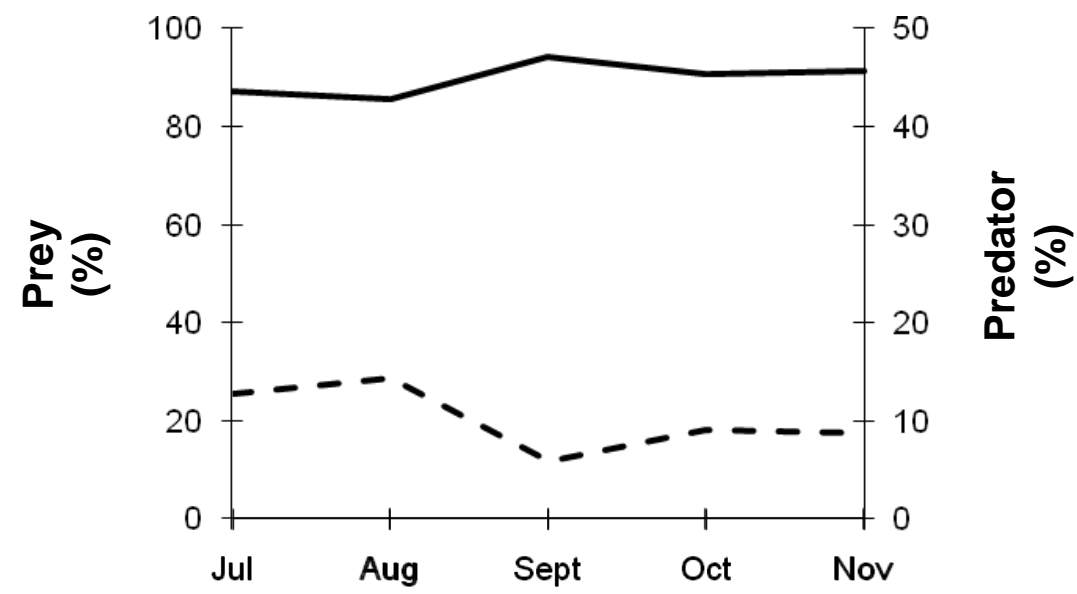

Figure 3. The relative abundance of prey and predator zooplankton group in Jakarta bay during research in July to November 2009.

The prey zooplankton which tively (Figure 4). Echinodermates reached showed single peak pattern are cirripeds, it peak in July with $4,854.75 \mathrm{ind} / \mathrm{m}^{3}$ and cladoceran, luciferids, mysids, bryozoans, was different from other prey zooplankton echinodermates and tunicates (Figure 4). observed in this research (Figure 4). Two Predatory zooplanktons which showed predatory zooplankton groups, which have single peak pattern are ctenophores and single peak pattern, were reached its chordates (Figure 5).

Cirripeds, luciferids, mysids, bryozoans, and tunicates were reached its peak in August, with abundance 17,762.63 ind $/ \mathrm{m}^{3}, 8,177.78 \mathrm{ind} / \mathrm{m}^{3}, 575.76 \mathrm{ind} / \mathrm{m}^{3}$, maxima in different month. The ctenophores reached its peak in September with $341.41 \mathrm{ind} / \mathrm{m}^{3}$, while chordates reached its peak in August with 707.07 $62.63 \mathrm{ind} / \mathrm{m}^{3}, 11,742.42 \mathrm{ind} / \mathrm{m}^{3}$ respec- 
The prey zooplankton which showed double maxima pattern are copepods, malacostracas, ostracods and molluscas (Figure 4), while predatory zooplankton which showed such pattern are cnidarians, chaetognaths, and polychaetes (Figure 5).

All zooplankton groups with double peak pattern reached its first peak in August and the second peak in October. It was different with the single peak pattern zooplankton group which has different peak time (Figure 4 and 5). In August copepods abundance were $14,430.30$ ind $/ \mathrm{m}^{3}$, malacostracans were 712.12 $\mathrm{ind} / \mathrm{m}^{3}$, ostracods were $402.02 \mathrm{ind} / \mathrm{m}^{3}$, molluscas were $968.69 \mathrm{i}$ ind $/ \mathrm{m}^{3}$, cnidarians 4,289.90 ind $/ \mathrm{m}^{3}$, chaetognaths were $3,280.81 \mathrm{ind} / \mathrm{m}^{3}$ and polychaetes were $1,718.18 \mathrm{ind} / \mathrm{m}^{3}$. In the second peak at October, copepods abundance were $19,081.68 \mathrm{ind} / \mathrm{m}^{3}$, malacostracas were $662.69 \mathrm{ind} / \mathrm{m}^{3}$, ostracods were 144.24 ind $/ \mathrm{m}^{3}$, molluscas were $317.91 \mathrm{ind} / \mathrm{m}^{3}$, cnidarians were $1,743.84$ ind $/ \mathrm{m}^{3}$, chaetognaths were $1,183.77 \mathrm{ind} / \mathrm{m}^{3}$ and polychaetes were $390.71 \mathrm{ind} / \mathrm{m}^{3}$.

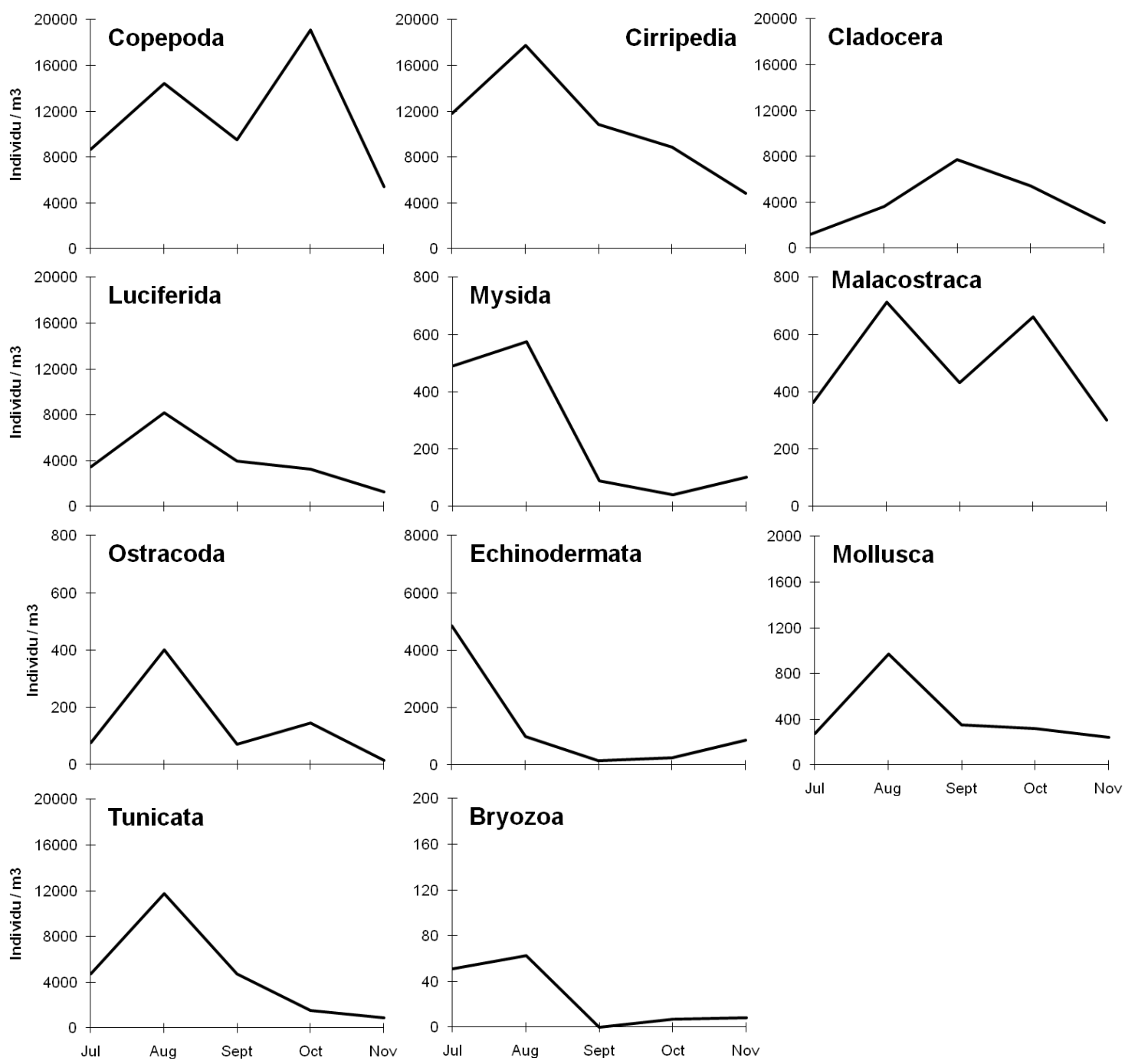

Figure 4. Abundance dynamic of prey zooplankton groups in Jakarta bay during research in July to November 2009. 


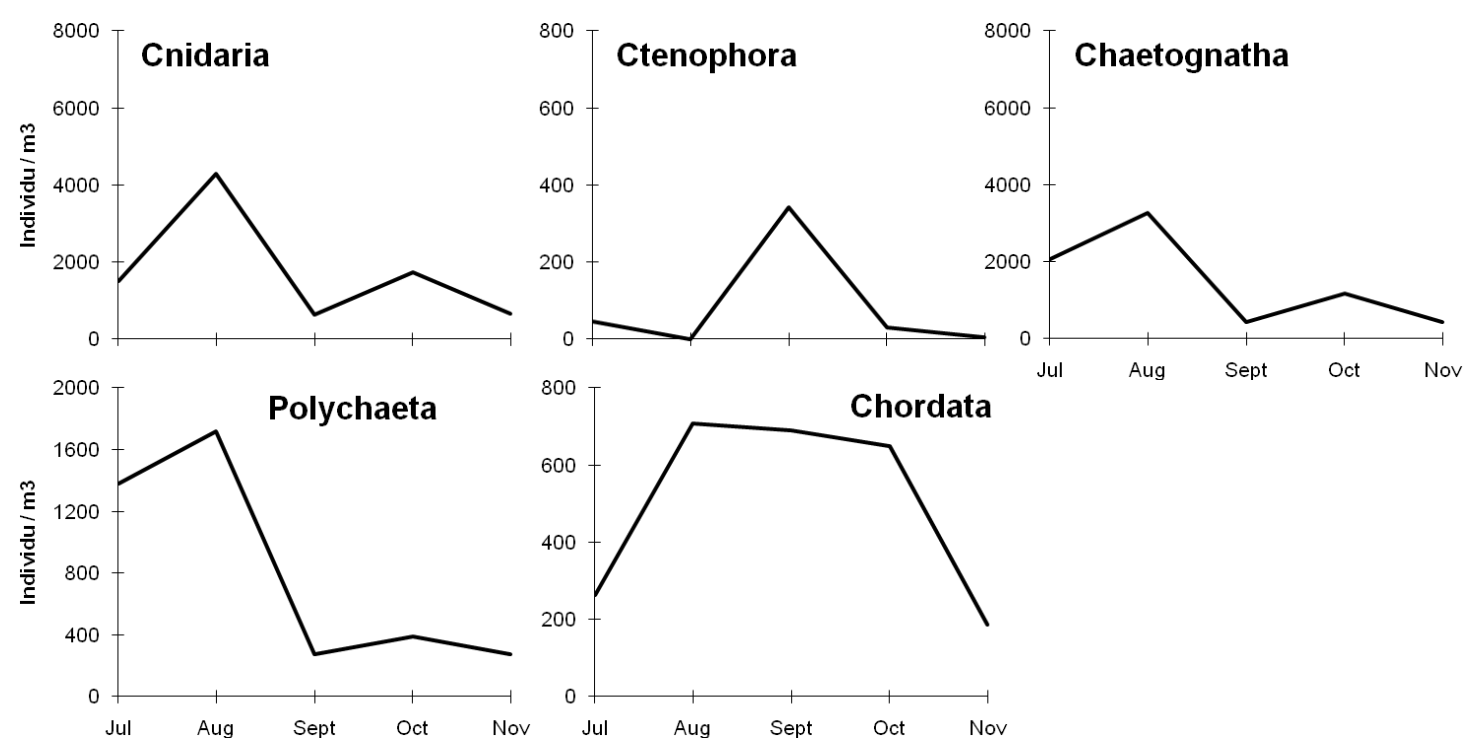

Figure 5. Abundance dynamic of predatory zooplankton groups in Jakarta bay in July to November 2009.

\subsubsection{The Dynamics of Zooplankton Relative Abundance in Jakarta Bay \\ It was interesting that the pattern} occurred in the zooplankton relative abundance (Figure 6 and 7) were different compared to the one occurred in its absolute abundance (Figure 4 and 5). The relative abundance of zooplankton groups showed its proportion occupied by those groups in the community. It also showed how its dominance changed during a time series research. Different from what occurred in zooplankton absolute abundance pattern, the pattern of zooplankton group relative abundance was specific for each group (Figure 6 and 7).

The double peak pattern in prey zooplankton groups' relative abundance was not occurred in most of the groups. Only ostracods still have its double peak pattern (Figure 6), with relative abundance of $0.58 \%$ in August and $0.33 \%$ in October. Copepods occupied its highest proportion in the community during October, with relative abundance of $43.74 \%$ (Figure 6). Cirripeds reach it peak proportion in November (Figure 6), with $27.30 \%$ of total zooplankton community, although it reached its lowest abundance in adjacent month (Figure 4). Lucifreids and tunicates still have its single peak pattern which occurred at August (Figure 6), with relative abundance of $11.77 \%$ and $16.90 \%$ respectively. Cladocerans and echinodermates were also still retaining its single peak which occurred in September and July respectively (Figure 6). During the peak in September, cladocerans have relative abundance of $19.19 \%$. Echinodermates relative abundance was $11.76 \%$ in its peak in July. Mysids highest relative abundance occurred in July, with $1.19 \%$ of total zooplankton abundance (Figure 6). Malacostracas highest occupation in zooplankton community occurred in November (Figure 6), with relative abundance of $1.38 \%$. 

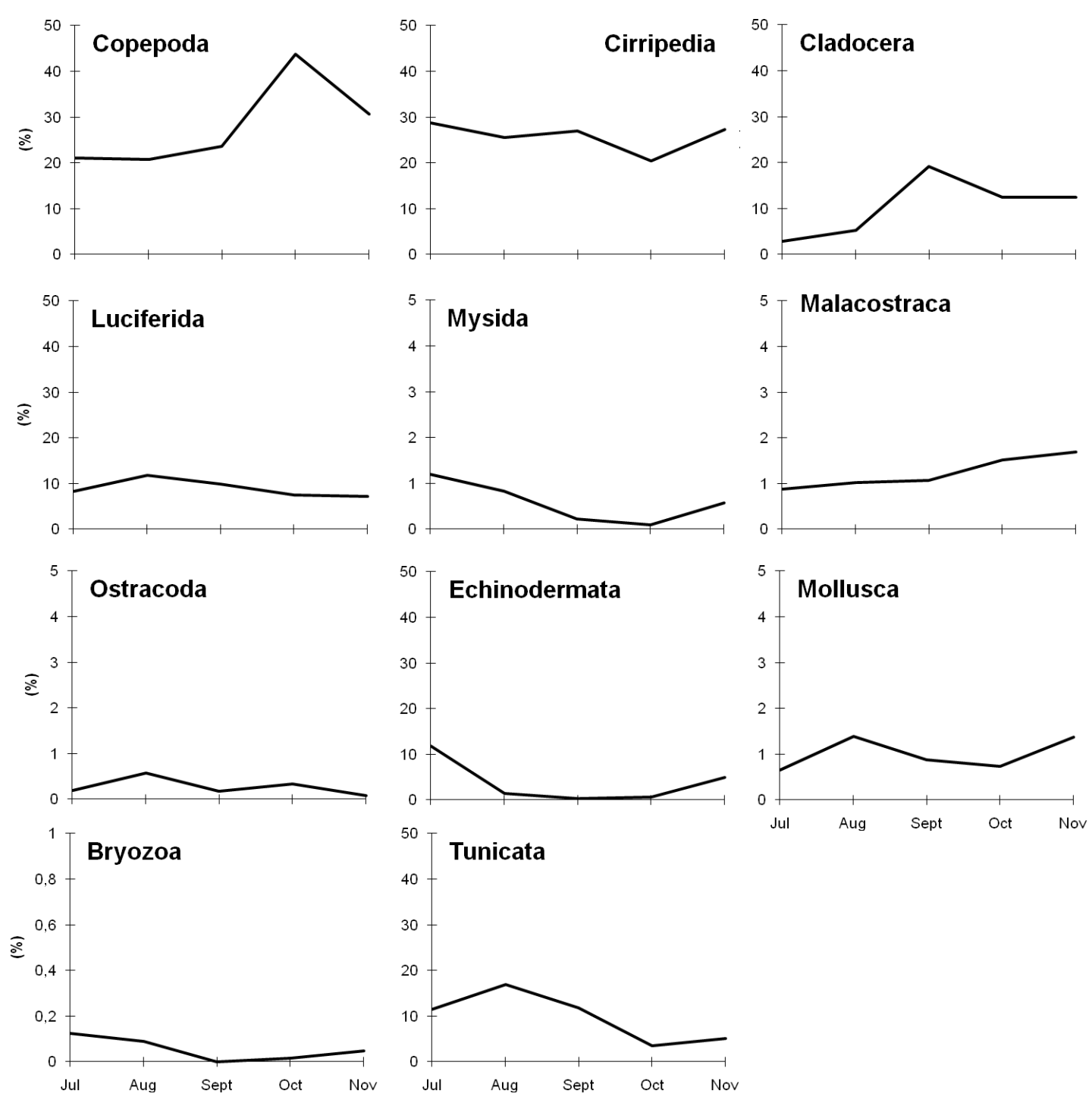

Figure 6. Relative abundance dynamic of prey zooplankton groups in Jakarta bay in July to November 2009.

Unlike prey zooplankton groups, abundance of $5.04 \%$ and $2.71 \%$. most of predatory zooplankton groups' Polychaetes seems to have double peak relative abundance still has the same pattern which peak happened in July and pattern as its absolute abundance (Figure 5 November (Figure 7), with relative and 7). Cnidarians still have double peak abundance of $3.34 \%$ and $1.55 \%$. pattern in its relative abundance which Ctenophores and chordates still retain its happenned in August and October (Figure single peak pattern which occurred in 7 ), with relative abundance of $6.17 \%$ and September (Figure 7), with relative $4 \%$, respectively. Chaetognaths also have abundance of $0.85 \%$ and $1.72 \%$, double peak pattern but occurred in July and October (Figure 7), with relative respectively. 

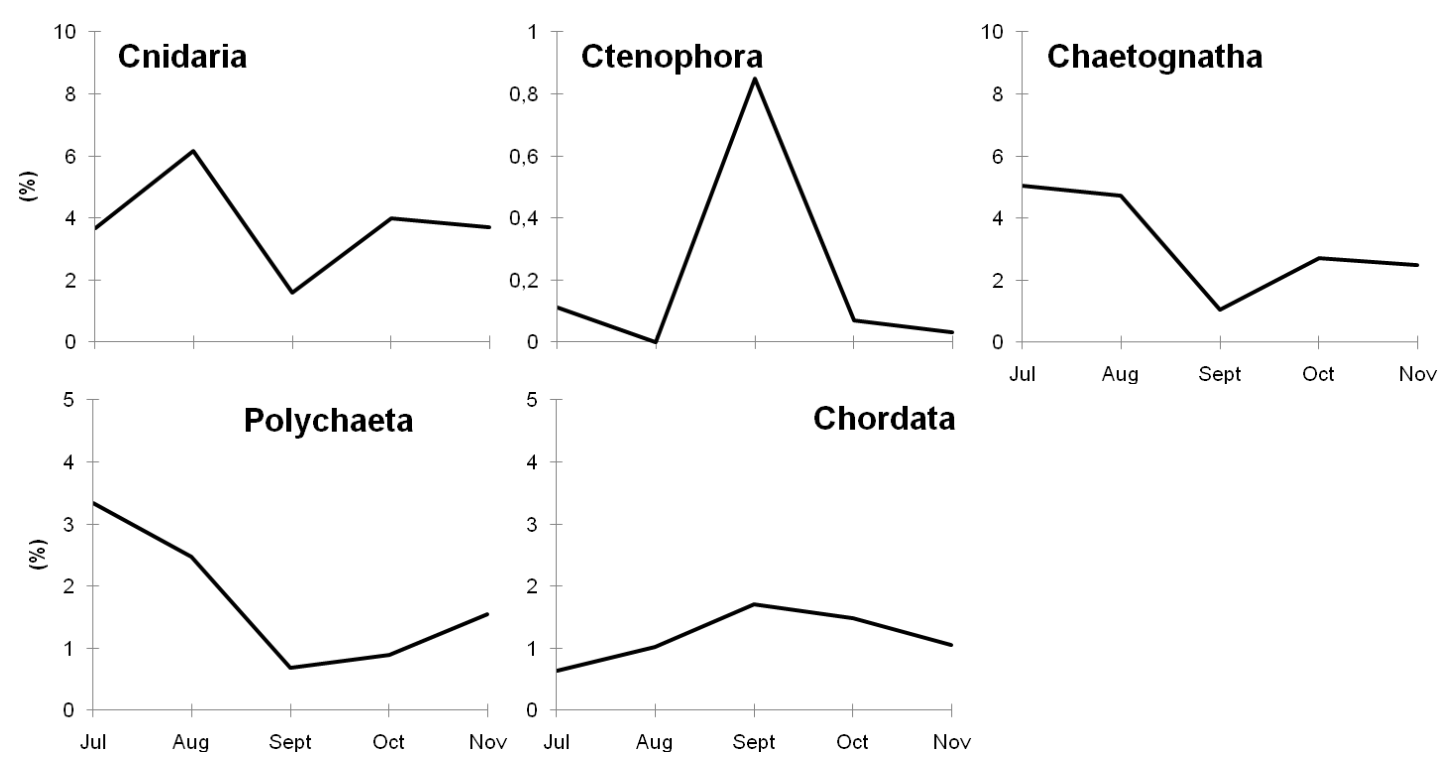

Figure 7. Relative abundance dynamic of predatory zooplankton groups in Jakarta bay during research in July to November 2009.

\subsubsection{The Dynamic of Physical- Chemical Parameters and Food Availability in Jakarta Bay}

Measurement of physical-chemical parameters shows that it was stable with relatively low variation during the investigation (Figure 8). The salinity in the water of Jakarta bay was varying between 27.9 to 34.03 and no extreme condition was found during this research (Figure 8). The water temperature of Jakarta bay water was relatively high, it varies between 28.3 to $30.27{ }^{\circ} \mathrm{C}$ (Figure 8). Similar to salinity, no drastic temperature change was observed during this research, especially since Jakarta bay was a tropical aquatic ecosystem which has no significant difference in water temperature all over the year (Nybakken and Bertness, 2005). The depth of Jakarta bay was varying in each sampling stations, starting from $4 \mathrm{~m}$ to $20 \mathrm{~m}$ deep. But the average depth of Jakarta bay water were relatively stable with slight variation in each month, which around 6.41 to 7.68 m. Water transparency showed highest variation between 5 sampling months, compared to other physic-chemical factors (Figure 8). The highest water transparency was observed during September which averaged at $3.77 \mathrm{~m}$. Due to the relatively stable condition of Jakarta bay water, it was assumed that physical and chemical parameters measured in this research were not the regulating factor of zooplankton community dynamic in the ecosystem.

Phytoplankton bloom was observed in August (Figure 9), with absolute abundance of $5,48 \times 10^{9}$ cells $/ \mathrm{m}^{3}$, indicating that phytoplankton as food for zooplankton was very abundant in August. Phytoplankton abundance then sharply declined in the next month (Figure 9). It was interesting to notice that the phytoplankton bloom was occurred at the same time with the peak of several zooplankton groups (Figure 4, 5, 6, and7). Thus there seems to be a relationship between high phytoplankton abundance and high zooplankton abundance in this research. But the second peak in some zooplankton groups might not related to the food availability, since as some groups reached its peak (Figure 4, 5, 6, and 7), 
the phytoplankton abundance were very low in Jakarta bay ecosystem (Figure 9).

\subsection{Discussion}

\subsubsection{Interaction Between Predator and} Prey Zooplankton in Jakarta Bay

The general pattern in predator and prey zooplankton absolute abundance (see Figure 2) in this research was similar with the model of predator-prey relationship in ecosystem proposed by RosenzweigMacArthur (Brewer, 1994; Krebs, 2009). The Rosenzweig-MacArthur model suggested that as the prey population increase, the predator population will increase as well. At high predator density, predator population stops increasing because of many factors, such as food limitation, increasing competition and cannibalism.

Based on the result, it was found that as the prey zooplankton abundance increase, the predatory zooplankton abundance also increases (see Figure 2). This was supported by a strong correlation between prey and predator zooplankton absolute abundance $(r=0.88)$. When the data of absolute abundance were converted to relative abundance, we notice that prey zooplankton occupied more proportion in zooplankton community when the predatory zooplankton relative abundance was decreasing (see Figure 3).
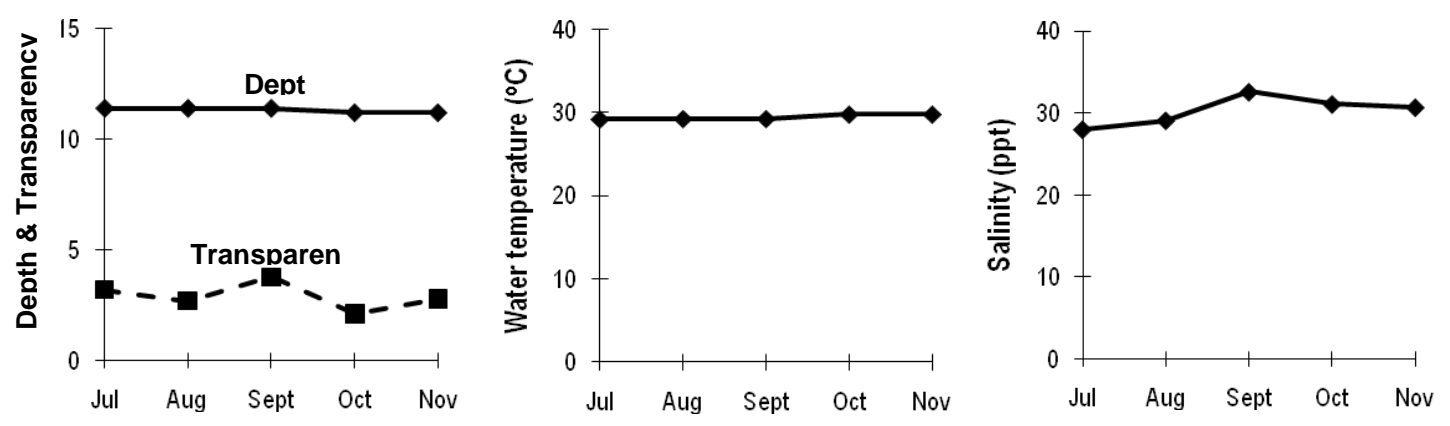

Figure 8. Water depth, temperature, and salinity in Jakarta bay during research in July to November 2009.

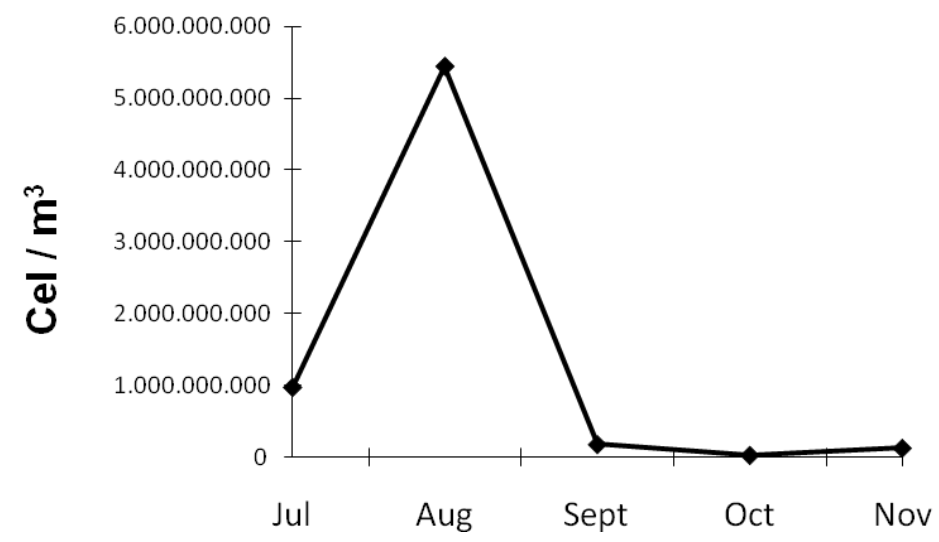

Figure 9. Phytoplankton density in Jakarta bay during research in July to November 2009. 
A very strong negative correlation between predator and prey relative abundance were observed in this research $(\mathrm{r}=-1)$. It suggested that when the predatory stress from predatory zooplankton was lowered, the prey zooplankton could increase its population thus occupy more space in zooplankton community. It was interesting to note that the first peak in prey and predatory zooplankton was occurred at the same time as the phytoplankton bloom phenomena (see Figure 2, 3, and 9). The prey zooplankton, which was phytoplankton grazer, seems response to the high density of phytoplankton in August by increasing its own population ( $\mathrm{r}$ $=0.8$. As the prey zooplankton population increasing, the predatory zooplankton, which feed on prey zooplankton, will also increase. The decline in prey zooplankton abundance in September might was related to the decline in phytoplankton abundance and the result of predatory pressure inflicted by predatory zooplankton.

Unfortunately the reason of the second increase in both prey and predator zooplankton population during October, was not clear. The low density of phytoplankton in September to November should limit the abundance of prey zooplankton (see Figure 9), yet the second peak in its abundance was occurred in October (see Figure 2 and 3). It might also was not related to the physical and chemical parameters in Jakarta bay, due to the stability of those factors during this research periods (Figure 8).

Result from TCI analysis showed an interesting pattern which suggest that the strength of bottom-up control was high (low TCI) during July to August (Figure 10). The increasing TCI value during September to October was the indication that the bottom-up control was gradually replaced by top-down control (Figure 10). Higher TCI value in September to October indicating a stronger top-down control in zooplankton community. Although the strength of top-down control was not very high (Figure 10), we suggest that it capable of causing a variation in zooplankton community dynamics, especially in prey zooplankton groups.

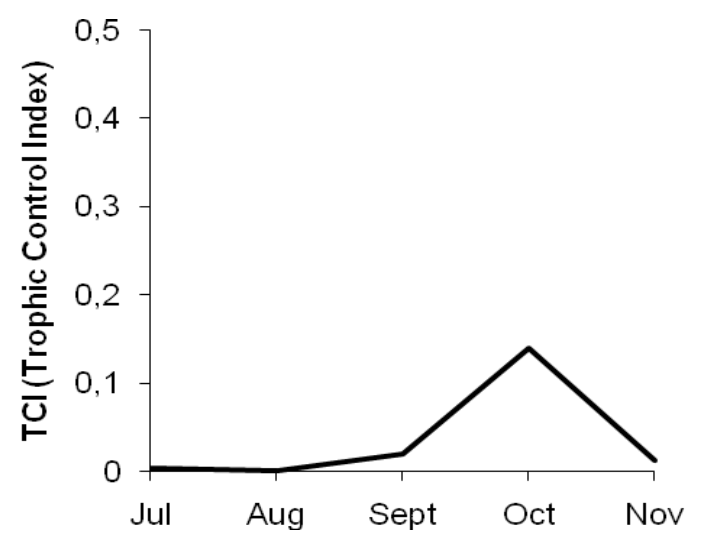

Figure 10. Dynamics of trophic control index (TCI) value in Jakarta bay during July to November 2009. 


\subsubsection{Variability in Abundance Pattern of Zooplankton Groups' in Jakarta Bay Related to Predator- Prey Interaction}

From the result now it assumed that the food availability was important factor which regulating the abundance of predator and prey zooplankton in Jakarta bay. Observation on each zooplankton groups revealed that there are two specific patterns in its abundance dynamic, the single peak and double peak (see Figure 4, 5,6 , and 7). These two distinct patterns were similar to two type of population growth curve proposed by Aldo Leopold, which were irruptive and cyclic type (Brewer, 1994). Single peak pattern in some zooplankton abundance dynamic most likely showing an irruptive type population growth, while the double peak pattern showing cyclic type population growth (see Figure 4 and 5).

Variability in zooplankton groups' abundance pattern was most likely related to the different response in food availability and predatory stress. In most prey zooplankton groups, the first peak was highly related to the phytoplankton bloom which occurred in August. Copepods, cirripeds, luciferids, mysids, malacostracans, osctracods, molluscs, tunicates, and bryozoans were prey zooplankton groups which reach the peak at August. Cladocerans, which also known as phytoplankton grazer (Raymont, 1983), didn't reach its peak at the same time at phytoplankton bloom phenomena. Cladocerans reach its peak when other prey zooplankton abundance was declining in September (see Figure 4). It was interesting to note that cladocerans peak was happened during the high abundance of its predator, the ctenophores and chordates (see Figure 5). We suggest that it might happen as the combination of: (1) lowered predatory pressure from other predatory zooplankton, such as cnidarians, chaetognathes and polychaetes. In this research we did found that cladocerans were negatively correlated with those three predatory zooplanktons; and (2) lowered competition pressure, as the competitor zooplankton abundance, such as copepods and cirripeds, were declined in September (Figure 4). The decline in most prey zooplankton group most likely related to the predation pressure by some predator zooplankton group (Figure 4).

It was interesting to note that the abundance of three predator zooplankton group, the cnidarians, chatognathes and polychaetes, were also decline in September. Meanwhile the abundance of ctenophores and chordates (fish larvae) were very high in adjacent month (Figure 5). Based on this data, we assumed that ctenophores might be the main predator for the most of zooplankton in Jakarta bay. The high abundance of ctenophores and chordates might be the cause of the low abundance or the decline in most of zooplankton group's abundance, including the other predatory zooplankton during September 2009 (see Figure 4 and 5). Data of their relative abundance in zooplankton community also support this assumption (see Figure 6 and 7). Ctenophores and chordates were occupied more proportion in zooplankton community in Jakarta bay during September (see Figure 7).

Ctenophores and chordates might feed on most zooplankton groups, including the other predatory zooplankton, thus reducing their abundance during high abundance of those two predator zooplankton group. We found that ctenophores were negatively correlated with nearly all prey zooplankton taxa, except the cladocerans. It also negatively correlated with all predatory zooplankton taxa, except the chordates. Meanwhile chordates were negatively correlated with two prey zooplankton group, the echinodermates and mysids. Ctenophores 
and chordates were known to feed on crustacean zooplankton, such as copepods, cladocerans, malacostracans, and luciferids (Wickstead, 1965; Roohi et al., 2006).

Thus, we suggest that ctenophores might be the main predator, as well as the top predator in the zooplankton community of Jakarta bay. Even with very low abundance, the ctenophores seem to be able to drive the dynamics of prey and other predatory zooplankton groups (see Figure 4, 5, 6, and 7). High TCI value in October (see Figure 10) was coincided with peak in some zooplankton groups and very low abundance of ctenophores in adjacent month (see Figure 4 and 5). This might indicate that the low abundance of ctenophores resulting in higher abundance of both prey and predatory zooplanktons, this happened due to lower predation pressure from ctenophores in adjacent month. Thus we suggest that ctenophores might be the keystone species in zooplankton community of Jakarta bay during our research. Unfortunately we cannot confirm this assumption since further intensive experimental experiment was needed to determine the role of ctenophores as keystone predator in Jakarta bay ecosystem.

Predation by predator zooplankton might act as ecological force that prevents the dominance of one prey zooplankton group. The predatory zooplankton might act as top-down control, which regulate the dynamics of prey zooplankton groups. Predation might also promote the coexistence balance between all zooplankton groups in Jakarta bay shallow water coastal ecosystem. The role of food availability (either phytoplankton or prey zooplankton) as the regulator of zooplankton abundance, were also regarded as ecological force that inducing the peak of some zooplankton groups. Food availability might act as bottom-up control, which regulate the dynamics of prey zooplankton groups. Thus we could conclude that biotic factors, such as food availability combined with the predatory pressure, were the main factors which regulated the dynamic of zooplankton abundance in Jakarta bay.

\section{Acknowledgement}

This research was conducted with the competitive research grants from DIKTI in 2009. We would express our sincere gratitude to Mrs. Hikmah Thoha, M.Sc., as lead scientist in Planktonology Laboratory at Research Center for Oceanography, for the very helpful discussion on our research theme. We also express our gratitude to Mrs. Elly Asniariati and Mrs. Sugestiningsih, our laboratory technicians whom helped us to enumerating zooplankton individuals and phytoplankton cells in our samples.

\section{REFERENCES}

Bakus, G. J. 2007. Quantitative analysis of marine biological communities: field biology and environment. John Wiley \& Sons, Inc. USA. 102106pp.

Brewer, R. 1994. The science of ecology 2nd ed. Saunders College Publishing. USA. 188-198pp.

Davis, C. C. 1955. The marine and freshwater plankton. Michigan State University Press. USA. 426p.

Escribano, R., P. Hidalgo, H. Gonzalez, R. Giesecke, R. R. Bugueno, and K. Manriquez. 2007. Seasonal and inter-annual variation of mesozooplankton in the coastal upwelling zone off central-southern Chile. Prog. Oceanography, 75:470-485.

Hadikusumah. 2008. Perubahan massa air di Teluk Jakarta sebagai indikasi perubahan iklim. In: Ruyitno (ed.). Kajian perubahan ekologis Teluk Jakarta. LIPI Press. Indonesia. 
Horne, A. J. and C. R. Goldman. 1994. Limnology, 2nd ed. McGraw-Hill, Inc. USA. 433-455pp.

Hsiao, S. H., S. Ka, T. S. Fang, and J. S. Hwang. 2011. Zooplankton assemblages as indicators of seasonal changes in water masses in the boundary waters between the East China Sea and Taiwan Strait. Hydrobiologia, 666:1-14.

Kinoshita, J., J. Hiromi, and Y. Yamada. 2006. Abundance and biomass of Scyphomedusae, Aurelia aurita and Chrysaora melanaster, and Ctenophora, Bolinopsis mikado, with estimates of their feeding impact on zooplankton in Tokyo Bay, Japan. J. Oceanography, 62:607-615.

Krebs, C. J. 2009. Ecology. 6th ed. Pearson Education Inc. USA. 189207pp.

Lenz, J. 2000. Introduction: Ecological position. In: Harris, R. P., P. H. Wiebe, J. Lenz, H. R. Skjoldal, and M. Huntley (eds.). ICES Zooplankon methodology manual. Academic Press. USA. 1-10pp.

Marques, S. C., U. M. Azeteiro, S. M. Leandro, H. Queiroga, A. L. Primo, F. Martinho, I. Vegas, and M. A. Pardal. 2008. Predicting zooplankton response to environmental changes in a temperate estuarine ecosystem. Mar. Biol., 155:531-541.

McAleece, N., P. J. D. Lambshead, and G. L. J. Paterson. 1997. Biodiversity pro: Free statistic software for ecology. The National History Museum, London. UK. http://gcmd.nasa.gov/records/NHML_Bio pro.html. Accessed in 21/07/2011.

Muchtar, M. 2008. Fluktuasi kandungan zat hara fosfat, nitrat, dan silikat di Teluk Jakarta. In: Ruyitno (ed.). Kajian perubahan ekologis Teluk Jakarta. LIPI Press. Indonesia.
Newell, G. E. \& R. C. Newell. 1963. Marine Plankton. A Practical Guide. Hutchinson of London. UK. $244 p$.

Nontji, A. 2008. Plankton laut. LIPI Press. Indonesia. 105-164pp.

Nybakken, J. W. \& M. K. Bertness. 2005. Marine biology: An ecological approach 6th Ed. Pearson Education Inc. USA. 42-98pp.

Pace, M. L., J. J. Cole, and S. R. Carpenter. 1998. Trophic cascades and compensation: differential responses of microzooplankton in whole-lake experiments. Ecology, 79:138-152.

Raymont, J. E. G. 1983. Plankton and productivity in the oceans volume 2: zooplankton. 2nd ed. Pergamon Press Ltd. UK.110p.

Reaugh, M. L., M. R. Roman, and D. K. Stoecker. 2007. Changes in plankton community structure and function in response to variable freshwater flow in two tributaries of the Chesapeake Bay. Estuaries \& Coasts, 30:403417.

Rilov, G. 2009. Chapter 15: Predator-prey interactions of marine invaders. In: Rilov, G. and A. Crooks (eds.). Biological invasions in marine ecosystems. Eco. Studies, 204:261285.

Roohi, A., A. E. Kideys, A. Sajjadi, A. Hashemian, R. Pourgholam, H. Fazli, A. G. Khanari, and E. EkerDeveli. 2006. Changes in biodiversity of phytoplankton, zooplankton, fishes and macrobenthos in the Southern Caspian Sea after the invasion of the ctenophore Mnemiopsis leidyi. Biol. Invasions, 12:2343-2361. 
Sidabutar, T. 2008. Kondisi plankton di Teluk Jakarta: kajian perubahan ekosistem perairan Teluk Jakarta. In: Ruyitno (ed.). Kajian perubahan ekologis Teluk Jakarta. LIPI Press. Indonesia. 113-133pp.

Sullivan, B. K., J. H. Costello, and D. Van Keuren. 2007. Seasonality of the copepods Acartia hudsonica and Acartia tonsa in Narragansett Bay, RI, USA during a period of climate change. Estuarine. Coast. Shelf. Sci., 73:259-267.

Uye, S., N. Nagano, and T. Shimazu. 2000. Abundance, biomass, production and trophic role of micro- and net-zooplankton in Ise Bay, Central Japan, in winter. $J$. Oceanogr., 56:389-398.

Vadeboncoeur, Y., K. S. McCann, M. J. V. Zanden, and J. B. Rasmussen. 2005. Effects of multi-chain omnivory on the strength of trophic control in lakes. Ecosystem, 8:682693.

Wickstead, J. H. 1965. An introduction to the study of tropical plankton. Hutchinson \& Co Publisher. United Kingdom. 160p.

Wickstead, J.H. 1976. The Institute of Biology's studies in biology no. 62: marine zooplankton. Edward Arnold Publisher Ltd. 22-24pp.

Woodmanse, R. A. 1958. The seasonal distribution of zooplankton off Chicken Key in Biscayne Bay, Florida. Ecology, 39:247-262.

Yamaji, I. 1966. Illustration of the marine plankton of Japan. Houkusho. Japan. $369 \mathrm{p}$. 